\title{
CROHN'S GRANULOMA OF SKIN IN IBD COLITIS
}

\section{Hardeep Singh Deep ${ }^{1}$, Vijay Kumar², Anumeet Singh Grover ${ }^{3}$}

\section{HOW TO CITE THIS ARTICLE:}

Hardeep Singh Deep, Vijay Kumar, Anumeet Singh Grover. “Crohn's Granuloma of Skin in IBD Colitis”. Journal of Evolution of Medical and Dental Sciences 2015; Vol. 4, Issue 09, January 29; Page: 1569-1573,

DOI: $10.14260 /$ jemds/2015/219

ABSTRACT: Crohn's granuloma is a sarcoid-like lesion, with collections of monocyte/macrophages cells (epitheloid histiocytes) and other inflammatory cells, including lymphocytes and eosinophils with occasional giant cells. They are seen rarely in extraintestinal sites. Crohn's granuloma is highly characteristic of Crohn's disease. It responds to treatment of Crohn's disease. A case report of 31 year old male patient with IBD colitis having Crohn's granuloma on left elbow. On treatment with prednisolone frequency of intestinal symptoms decreased and the ulcerative lesion also healed. Then azathioprine was given for definitive management.

KEYWORDS: Crohn's Granuloma, Crohn's disease.

INTRODUCTION: The incidence rate of Inflammatory Bowel Disease (IBD) in South Asian patients for the period 1996-2001 was 15.19/10 [6.41/10 for Crohn's Disease (CD), 6.70/10 for Ulcerative Colitis (UC), and 2.08/10 for Inflammatory Bowel Disease-Unclassified(IBD-U)].[1] The presence of granuloma is highly characteristic of CD and is not found in UC. Crohn's granuloma is a sarcoid-like lesion, with collections of monocyte/macrophages cells (epitheloid histiocytes) and other inflammatory cells, including lymphocytes and eosinophils with occasional giant cells. Granulomas are commonly seen in the intestinal tract but they can also be seen rarely in skin, eye, and liver (Extraintestinal Granulomas).[2] IBD colitis (ulcerative colitis or crohn's disease) is immune mediated chronic condition of colon and small intestine. [3] Crohn's granuloma is highly characteristic of crohn's disease, it is never found in ulcerative colitis even on extensive review of literature no or little association between crohn's granuloma and UC has been found.

CASE REPORT: A 31 year old male presented with chief complaints of loose stools 6-8/day, blood and mucus stained, along with tenesmus for more than 6 months. Ulcerative lesion (app.size $3 \mathrm{~cm} \mathrm{x}$ $2 \mathrm{~cm}$ ) on the left elbow was present for 2 months with discharging pus which increased with flare up of intestinal symptoms. There was h/o moderate grade fever associated with rigor and chills.

EXAMINATION: On presentation, patient was fully conscious, oriented to time, place and person. Blood pressure was 120/70mm of $\mathrm{Hg}$, Respiratory rate was14/min, Pulse rate was 90/min and oral temperature was 98.40F. Cardio-Respiratory and Abdominal examination were normal. He had ulcerative lesion on elbow with discharging pus (as shown in figure no. 1-3). Cardio-Respiratory and Abdominal examination were normal.

INVESTIGATIONS: Hb was 12.2 (13-16 gm\%), TLC was 7600 (4000-11000/mm³), Platelet count was

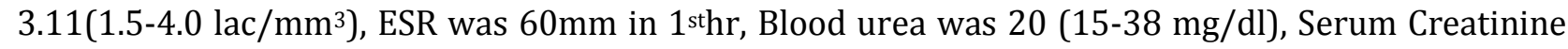
was 0.7(0.6-1.3 mg/dl), Serum Sodium was 137 (135-148 mEq/l), Serum Potassium was 4.5 (3.5-5.5 $\mathrm{mEq} / \mathrm{L}$ ), C-Reactive Protein was $23.0 \mathrm{mg} / \mathrm{L}(<5 \mathrm{mg} / \mathrm{L}$ ), Stool for CDTA (Clostridium difficile toxin 


\section{CASE REPORT}

assay) was negative. Colonoscopy (as in figure 4-7) showed edematous mucosa with loss of mucosal vascular pattern, hyperemia, granularity, friability and ulceration in rectum, sigmoid and descending colon. Changes were continuous with no skip lesions. Skin biopsy (as in figure 8-10) showed many periadnexal epitheloid cell, granuloma composed of epitheloid cell, lymphocyte, plasma cell and multinucleated giant cell. Normal looking adnexa and vessel were seen within the dermis along with fibroconnective tissue infiltrated with inflammatory cell. PCR (polymerase chain reaction) for mycobacterial tuberculosis was negative.

MANAGEMENT: Patient was initially diagnosed as a case of UC with Pyoderma left elbow. Patient was treated with antibiotics for one month for ulcerative skin lesion. Biopsy of ulcer on skin suggested Crohn's granuloma (Metastatic Crohn's Disease). Intestinal symptoms did not respond to mesalamine which was started as initial treatment. Subsequently, prednisolone was given to the patient. Frequency of intestinal symptoms decreased and the ulcerative lesion also healed after prednisolone. Then azathioprine was given for definitive management.

DISCUSSION: Patient presented with h/o blood and mucus in stools. Colonoscopy showed findings of UC. There was no response to mesalamine given initially but intestinal symptoms and ulcerative skin lesion improved with prednisolone which was administered later. This response favoured the diagnosis of IBD Colitis/Crohn's colitis with Crohn's granuloma of skin well supported by histopathological examination report of the skin lesion. Histologically Metastatic Crohn's Disease usually show noncaseating granuloma within dermis, occasionally extending into the subcutaneous tissue. In some cases the granuloma were arranged perivascularly but vessel wall were normal.[4] Crohn's granuloma at sites other than intestinal site is very rare and seen in metastatic crohn's disease. [5] There is no consistent relationship between appearance of metastatic lesion and activity of bowel disease. Although in our patients lesion tend to appear when gastrointestinal disease was active, other reports have described lesion appearing when bowel disease was quiescent.[6] This is a rare case of IBD Colitis with crohn's granuloma [Metastatic Crohn's Disease].

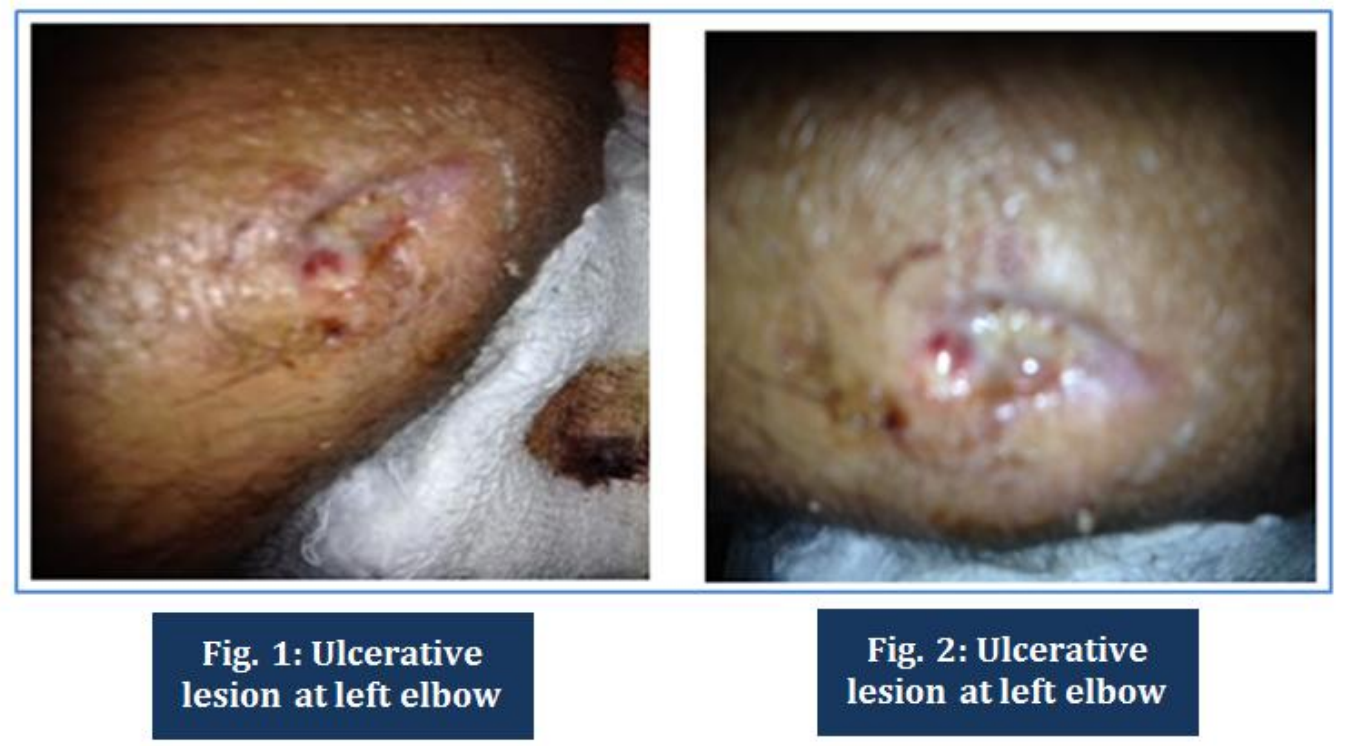

J of Evolution of Med and Dent Sci/ eISSN- 2278-4802, pISSN- 2278-4748/ Vol. 4/ Issue 09/Jan 29, 2015 


\section{CASE REPORT}

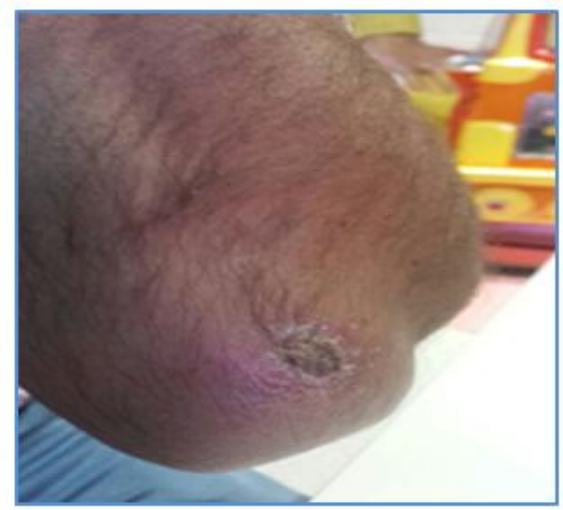

Fig. 3: Healing of ulcerative lesion at left elbow

\section{ULCERATIVE LESION AT LEFT ELBOW: COLONOSCOPY:}

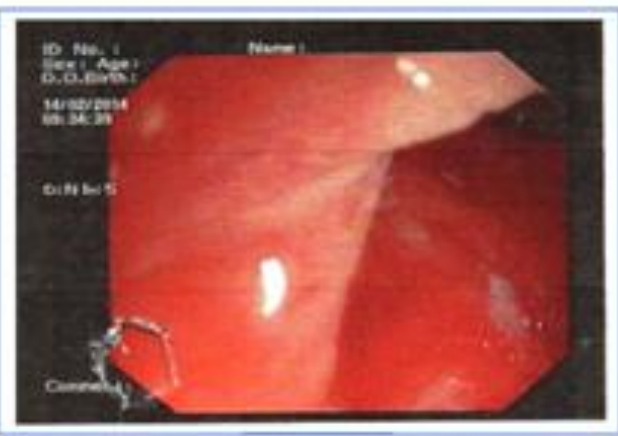

Fig. 4: Erosions, erythma, loss of vasularity and friability in rectum

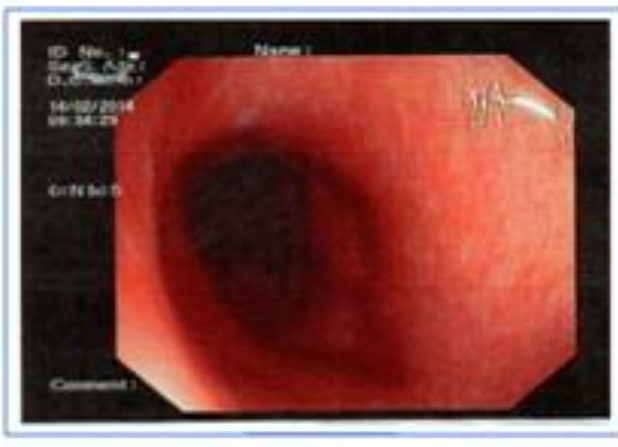

Fig. 5: erosions, erythma, loss of vasularity and friability in sigmoid colon

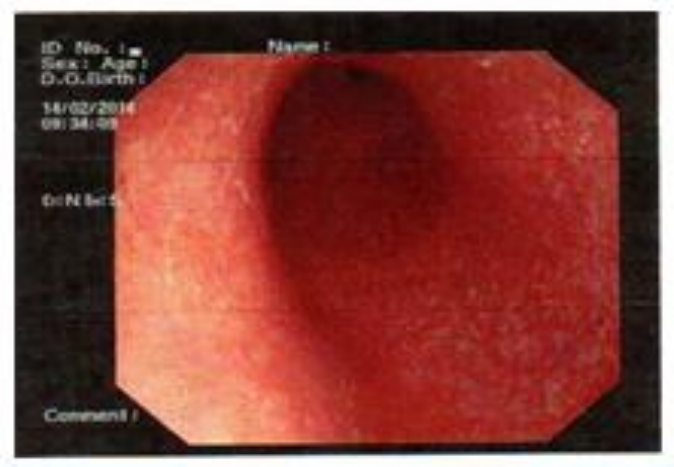

Fig. 6: erosions, erythma, loss of vasularity and friability in transverse colon but less marked 


\section{CASE REPORT}

\section{SKIN BIOPSY (HEMATOXYLIN AND EOSIN STAINED):}

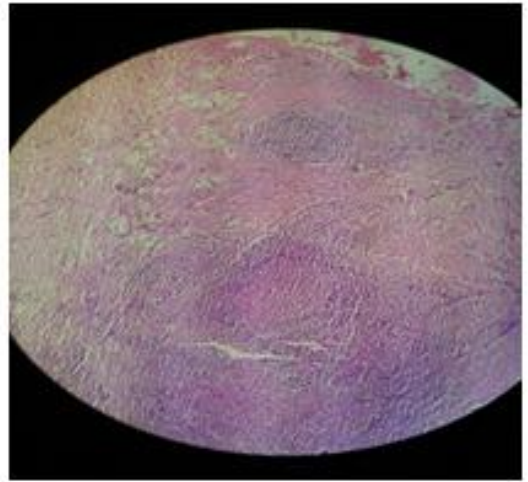

Fig. 7: Histopathology of skin biopsy

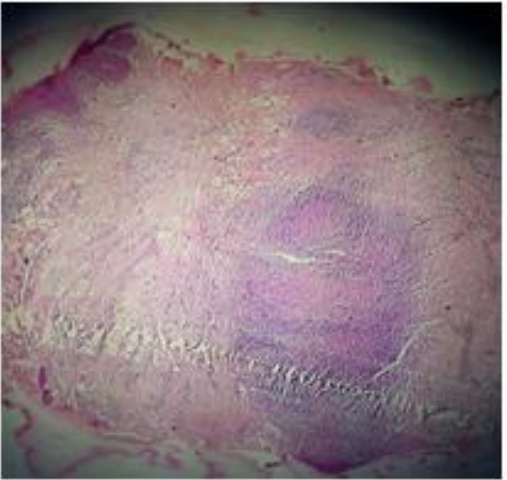

Fig. 8: Histopathology of skin biopsy

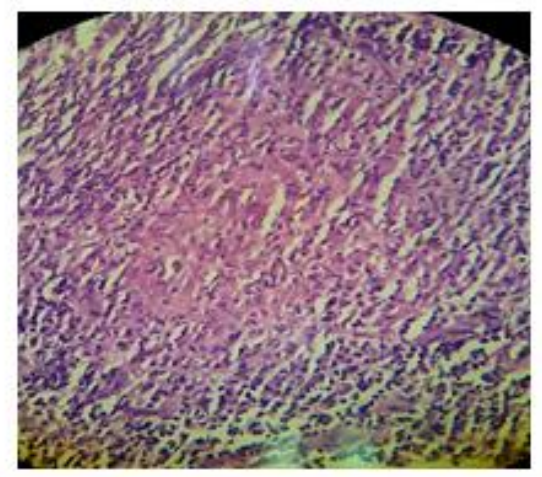

Fig. 9: Histopathology of skin biopsy

\section{REFERENCES:}

1. Pinsk V, Lemberg DA, Grewal K, Barker CC, Schreiber RA, Jacobson K. "Inflammatory bowel disease in the South Asian pediatric population of British Columbia," American Journal of Gastroenterology, vol. 102, no. 5, pp. 1077-1083, 2007.

2. Sands BE, Seigel CA, Crohn's disease, In:Feldman M, Freidman LS, Brandt LJ Editors. Sleisenger and Fordtran's Gastrointestinal And Liver Disease. 9th ed. Philadelphia. Sanders Elsevier. 2010; 111: 1948.

3. Friedman S, Blumberg RS, Inflammatory bowel disease. In:Longo DL, Fauci AS, Kasper DL, Hauser SL, Jameson JL, Loscalzo J, Editors, Harrison's Principles of Internal Medicine. $18^{\text {thed. }}$ New York. McGraw Hill. 2012: 295:2477.

4. Witkowski Ja, Parish Lc, Lewis Je. Crohn's Disease Non Caseating Granulomas On Legs, Acta Derma Venereol 1997; 57: 181-3.

5. Siroy A, Wasman J, Metastatic Crohn Disease, Rare Cutaneous Entity:Arch Pathol Lab Med. 2012; 136: 329-332).

6. Goolamali Sk, Price A Extensive Cutaneous Crohn's Disease Br J Dermatol1963; 109 (Suppl 24): $86-7$. 


\section{AUTHORS:}

1. Hardeep Singh Deep

2. Vijay Kumar

3. Anumeet Singh Grover

\section{PARTICULARS OF CONTRIBUTORS:}

1. Professor, Department of Medicine, Shri Guru Ram Dass Institute of Medical Science.

2. $2^{\text {nd }}$ Year Resident, Department of Medicine, Shri Guru Ram Dass Institute of Medical Science.
3. Assistant Professor, Department of Gastroenterology, Shri Guru Ram Dass Institute of Medical Science.

\section{NAME ADDRESS EMAIL ID OF THE CORRESPONDING AUTHOR:}

Dr. Hardeep Singh Deep,

\# B-337, Ranjit Avenue, Amritsar.

E-mail: deephardeepsingh51@gmail.com

Date of Submission: 05/01/2015.

Date of Peer Review: 06/06/2015.

Date of Acceptance: 19/01/2015.

Date of Publishing: 29/01/2015. 